表 17 重複癌予後

1984. 4. 1. 現在

\begin{tabular}{|c|c|c|c|c|}
\hline \multirow{2}{*}{ 転㷌 } & \multirow{2}{*}{ 同時性 14 例 } & \multicolumn{2}{|c|}{ 異 時 性 } & \multirow{2}{*}{ 三重複癌 2 例 } \\
\hline & & 大晹癌先行 15 例 & 他葴器癌先行 15 例 & \\
\hline 死亡 & 10 & 10 & 7 & (直) $\frac{1}{(\text { 男・食道 })}$ \\
\hline \multirow[t]{2}{*}{ 生存 } & $\begin{array}{c}4 \\
(6 \text { 月～} 16 \text { 年 }) \\
\text { 平均 } 8 \text { 年 }\end{array}$ & $\begin{array}{c}5 \\
(5 \text { 年 } 8 \text { 月 } 15 \text { 年 }) \\
\text { 平均 } 10 \text { 年 }\end{array}$ & $\begin{array}{c}(1.5 \text { 年 } 13.5 \text { 年) } \\
\text { 平均 } 6 \text { 年 }\end{array}$ & 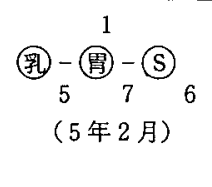 \\
\hline & $\begin{array}{l}\text { 胃癌(早 } 3 \\
\text { 乳癌 } 1\end{array}$ & $\begin{array}{l}\text { 胃癌(早) } 2, \mathrm{pml} \\
\text { 乳癌 } 1 \\
\text { 子宮癌 } 1\end{array}$ & $\begin{array}{ll}\text { 子宮㿔 } & 4 \\
\text { 胃㿋 } & 2 \\
\text { 乳癌 } & 2\end{array}$ & \\
\hline
\end{tabular}

\section{診 断}

最近数年間にみられる癌診断技術の進歩は，信頼度の 高いUS・CT など画像診断の導入により，革命的な登 展ぶりを遂げた. US 下に㧍ける穿刺・生検は術中診断 にも有用で亦り，CT 画像に上る腫瘤の局在診断・浸潤 拡大の微細な描写など，術後の follow up にも久くこと のできない診断の手法となった. 一方血清診断としての CEA 值測定は，肝転移ばかりでなく局所再発でも緩除 ながら上昇し，術前高值のものでは術後綿密に反復実施 することによって，再発形式の推定にも有用である．直 腸癌の局所再発の大方は会陰部再発で，初徽確認ですら 前述のごとく術後平均20ケ月であるので，局所再発の起 りはかなりこれに先行してるはずである．局所再発を一 刻も早く発見し適切な対応をすることは，手術予後の改 善に重要なことで，自覚症状の発現を待つことなく，術 前掠上び術後 ( 3 週閒目前後) CT 画像をとり, 術後 2 年間は 3 ケ月ないし半年毎につう゚け，再発モニターとし て CEA 值测定はできるだけ再三反復する必要がある。 胃癌とは異り直腸癌の局所再発は骨盤内再発であるの で，再発といえども対态いかんによっては再手術による 治療の可能性む高いと思われる.

\section{結 語}

直腸癌に局所再発が多いことはわれわれ外科医にとっ て大きな問題点であるが，直腸癌の根治手術には，排便 ・排尿・性機能障害が必発で，これら後遺症は患者の日 常生活に重大な影響を与えるという実情がある．局所再 発に好箇の条件下にある直腸癌殊に下部直腸癌に対する 外科的対応には，今後工夫検討を要する多くの課題が残 されている，再発という場からその一端にふれた。

\section{会 長 講 演}

\section{直腸癌に対する前方切除術とその予後について}

札榥医科大学第 I 外科

早坂混

近年，食生活の欧米化と高龄化社会の発展に伴ない， わが国の大腸癌発生率は年を追うごとに増加の一途をた どっており，われわれの教室においても過去10年前に比 較して約 2 倍ちかい手術数となっている，その大部分は 直腸癌で占められ，したがって值腸癌手術数の増加とな って表われている。

今日，術後機能障害ならびに機能保全手術に対する関 心が高まりつつあるが，種々の機能障害を伴いやすい直 腸癌手術もその例化もれず，従来からさまざまな術式が 考案開発されている. 今回は直腸癌に対する機能保全手 術のなかで数多く施行されている直腸前方切除につい て，教室例の予後と全国アンケート集計の結果を中心に 2,3 の問題点について述べる.

\section{1. 直腸癌手術術式の変遷}

1974年1月から1983年12月までに教室で施行した直腸 癌手術は 273 例で，同期間内に施行した大腸癌手術総数 431 例の $63.3 \%$ に相当する. 273 例を術式別に分けると直 腸切断術が 125 例で最も多く，低位前方切除術が54例と 続くが，直腸切断術に比較して低位前方切除術の割合が 年とともに増加する傾向にある（表 1 ）。

図 1 亿1983年まで10年間に沶ける教室の直腸癌手術術 式の変遷を表わしたが，1974年の10年前には直腸癌症例 も少なく，な扔かつ低位前方切除術施行例の割合は極端 に少ないのに対して直腸切断術施行例が大部分を占めて 
表 1 直腸癌手術施行 273 例

$(1974.1 \sim 1983.12)$
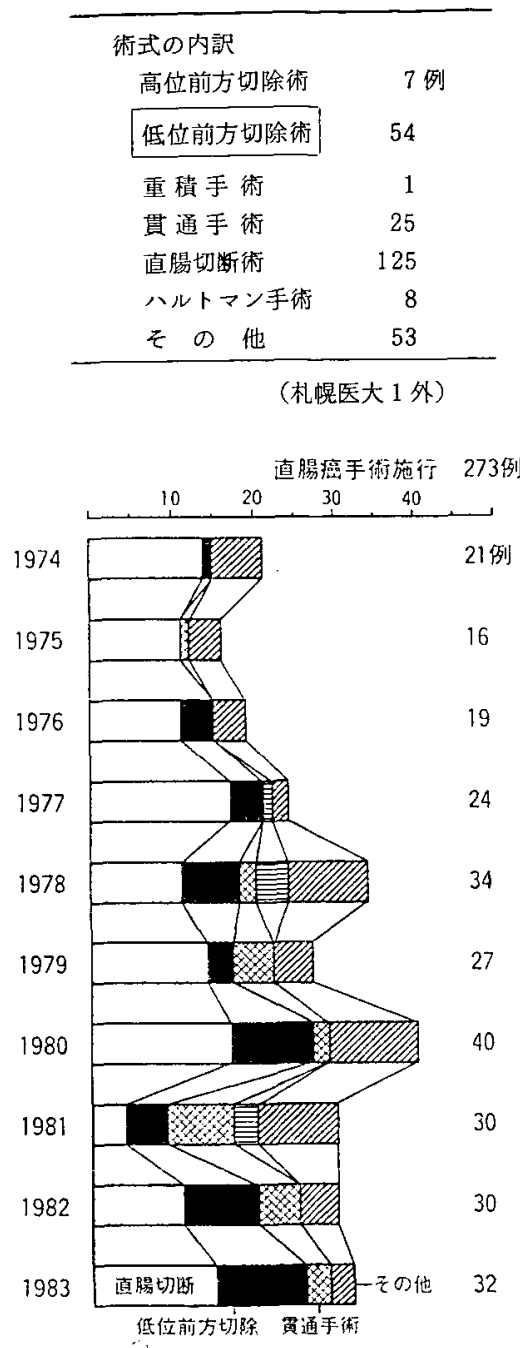

図 1 直腸癌手術術式の変遷(教室例) (1974 1983)
いる.しかし，年を追うごとに低位前方切除術施行例が 増加し, 直腸切断術施行例が減少する傾向が認められ る.

全国集計（116施設）の結果（図2）をみても同様であ り，1974年当時，60\%以上を占めた直腸切断術は減少し， 年を追うごとに低位前方切除術が確実に増加している.

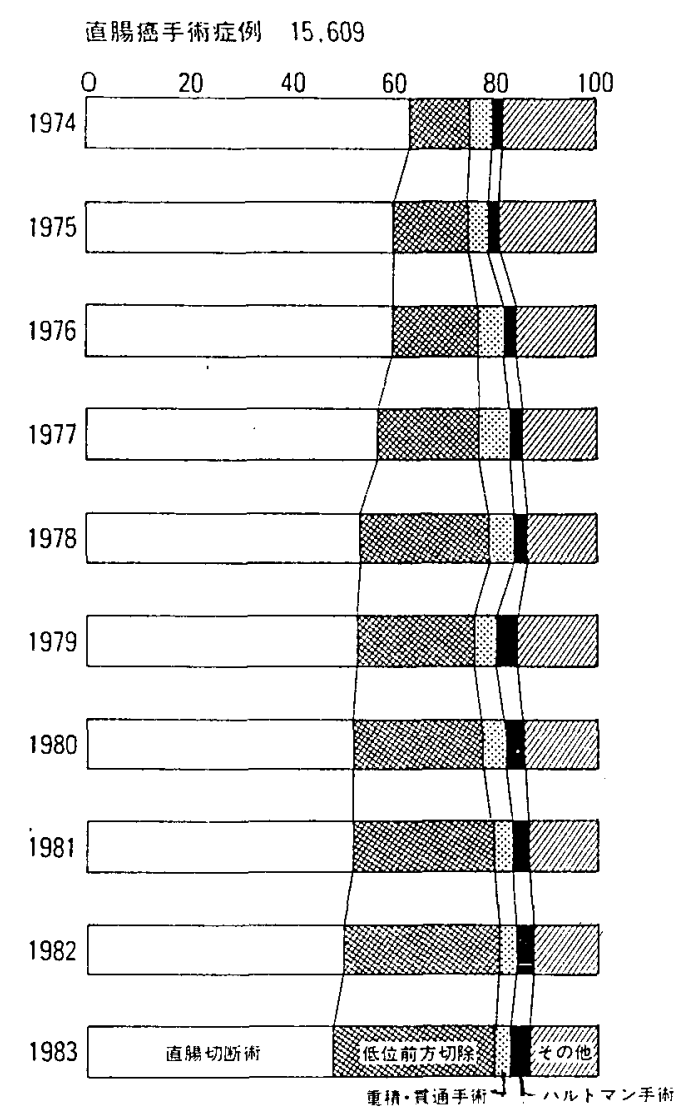

図 2 直腸癌手術術式の変遷 (アンケート調查 : 116施設)

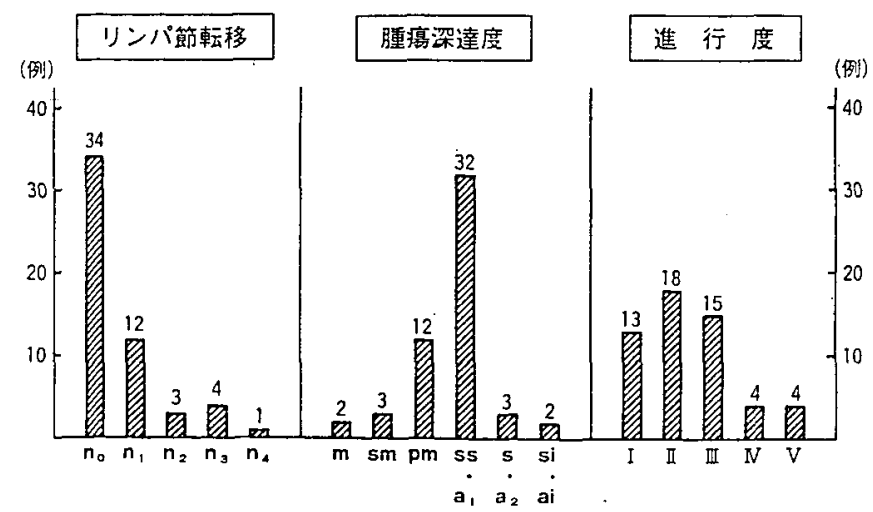

図 3 低位前方切除例门組織学的所見と進行度（教室例，1974-1983） 


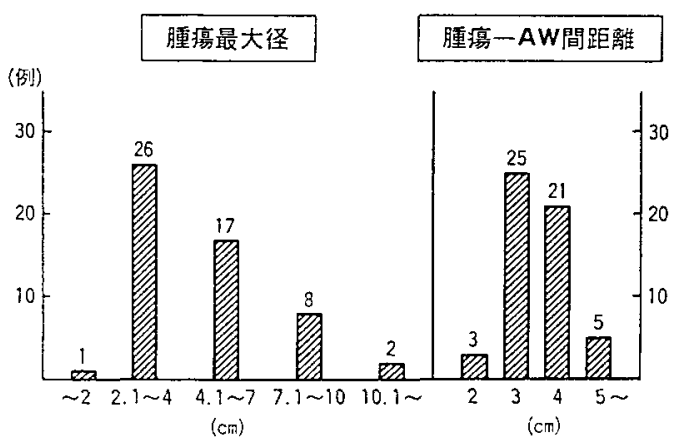

図 4 低前切の腫瘍最大径亡腫痨〜肛門側断端距離 (教空例，1974-1983）

2. 低位前方切除術施行例のリンパ節転移, 腫瘍深達 度と進行度

低位前方切除術を施行した 54 例についてリンパ 節転 移，腫潪深達度，進行度など腫瘍側の条件を検討すると 図 3 に示すとおりである.

寸なわち，リンパ節への転移状況では $\mathrm{n}_{0}$ 症例が 34例 (63\%) と最も多く，ついで $\mathrm{n}_{1}$ 症例が12例 (22.2\%) を 占め, 進行程度の軽度のものが適応とされる反面, わず かながら n $\mathrm{n}_{2}$ 以上の症例にも施行されているが，根治性 のえられない症例においても人工肚門を避ける意味で本 術式が選択されたことを示す.

腫瘍深達度では ss, a1症例が最も多く, 32例 (59.3\%) を占め，ついで pm 症例が12例 $(22.2 \%)$ となり，壁外浸 潤の強い症例には適応されずらいことを意味している.

進行度別に検討すると stage II 18例 (33.3\%), stage III 15例 $(27.8 \%)$, stage I 13例 $(24.1 \%)$ となり, stage III までの症例に多く施行されている。

3. 低位前方切除術施行例の腫瘍最大径と腫瘍一肛門 側断端距離

図4 低低前切を施行した症例の腫癔最大径扝よび腫瘍 - $\mathrm{AW}$ 䦎距離を示す. 腫瘍最大径をみると $2 \mathrm{~cm}$ 以上 $4 \mathrm{~cm}$ 以内の症例が26例 (48.1\%) で最も多く，ついで $4 \mathrm{~cm}$ 以上 $7 \mathrm{~cm}$ 以内が17例 $(31.4 \%)$ だ, $7 \mathrm{~cm}$ 在こえ る症例は根治性の面からも本術式の適応が少なく，10例 (18.5\%) にすぎない.

一方, 腫瘍一 $\mathrm{AW}$ 䦎距雄をみると $2 \mathrm{~cm}$ 以上 $3 \mathrm{~cm}$ 以 内の症例が 25 例 $(46.3 \%)$ で最も多く, ついで $3 \mathrm{~cm}$ 以 上 $4 \mathrm{~cm}$ 以内が 21 例（38.8\%）で両者で大半を上めてい る。それに対して $2 \mathrm{~cm}$ までの症例， $5 \mathrm{~cm}$ を超える症例 はそれぞれ 3 例 $(5.6 \%) ， 5$ 例 $(9.3 \%)$ と少なくなって いる.

4. アンケート調査 (116施設) からみた低位前方切除 術の適応条件（図 5,6 )
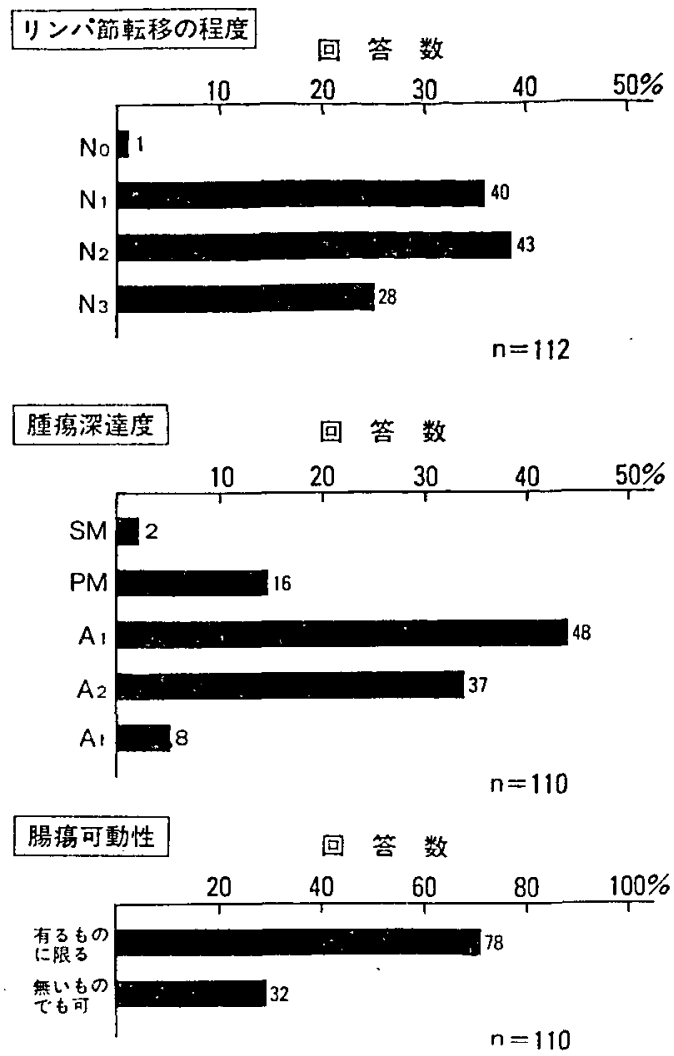

（数字は実数を示す）

図 5 低位前方切除の適応条件（アンケート調查）

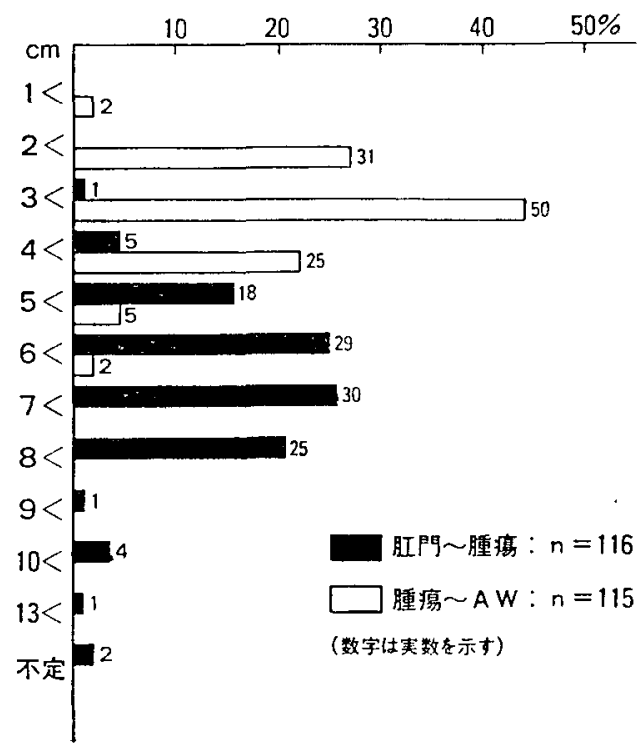

図 6 低位前方切除と肛門縁〜腫湯間距離および 腫瘍〜肛門側断端 (AW) 距離

(アンケート調查) 
1）リンパ節転移の程度

・リンパ節転移がどの程度までの症例を適応と考えてい るかを調查すると 2 群リンパ節までの症例を適応とする との回答が最も多く，それについでやや少ないが 1 群り ンパ節までとする回答が目立っており，それぞれ 38.4 \%，35.7\%を占め，3群リンパ節まで可とする回答は25 \%であった。

\section{2) 腫瘍深達度}

腫瘍深達度で最も回答が多かったものは $\mathrm{A}_{1}, \mathrm{SS}$ まで とするもので $43.6 \%$ 占め，ついで $\mathrm{A}_{2}, \mathrm{~S}$ まで可とす るものが33.6\%でほぼ妥当なところと考えるが，根治性 を重視して PM までを適応と考える意見が14.5\%を占 めるほか，SM までの早期癌のみを対象とすべきである とする極端な意見も少数ながら見受けられる。

3）腫值の可動性

可動性のある症例のみを対象とすべきであるとの意見 が71\%を占め，あくまでも根治性を重視した考えかたと みられる，それに奶して可動性がこしい場合でし積極的 に本術式を採用しょうとする意見が $29 \%$ にみらる。

4）肛門縁方ら腫癔下縁までの距離

低位前方切除術の適応を決定する場合に最初に問題と なるのが腫癔占居部位である.図 6 は肛門緣から腫瘍下 縁までの距離を黑塗りバーで示したが， $6 \mathrm{~cm}(25 \%)$, $7 \mathrm{~cm}(25.9 \%) ， 8 \mathrm{~cm}(21.6 \%)$ 離れた症例が多く，手 術手技の難易度，術後排便機能を考虑に入れると妥当な ところと考えられる.しかしながら一定の条件を設定せ す，可能なかぎり本術式を採用すべきであるという積極 的な意見もみられる．近年，全国的に広く普及しつつめ る腸管自働吻合器の応用により，従来，考えられてきた よりむ低位の前方切除例が増加することが予想される。

術中に問題となる腫瘤から肚門側断端までの距離を図 6 の白抜きのバーで示したが， $3 \mathrm{~cm}$ 離すとする意見が 圧倒的に多く，43.5\%を占め，ついで $2 \mathrm{~cm} \mathrm{が} 27 \% ， 4$ cm が21.7\%となっているが，あくまでも浸潤俱向の少 ない腫瘍に対していえることであり，とくに $2 \mathrm{~cm}$ で可 とする意見の中には限局型の $\mathrm{pm}$ 癌にかぎるとした回 答が多く占められている.

\section{5. アンケート調查からみた低位前方切除術の非適応} 症例 (表 2)

前項で低位前方切除術施行症例の各種条件を教室例市 よび全国集計の結果で検討したが，さらに低前切の適応 には問題があると考える症例についてアンケート結果を 検討した。

腫瘍の転移状況については，肛門側への逆行性リンパ 節転移のある症例，肚門挙筋への浸潤，遠隔リンパ節転 移のある症例，他葴器浸潤を伴なう症例などで，根治性
表 2 低位前方切除術の非適应症例

(テンケート調查)

転 移 状 況：肛門側リンパ節転移のある症例 肛門举筋への転移がある症例 遠隔リンパ節転移がある症例 他澸器浸潤 (Ai) 症例

腫瘍の局所条件：腫煬が全周におよぶ症例 腫瘍最大径 $5 \mathrm{~cm}$ 以上の症例 非限局型腫瘦

組 織学的条件：低分化癌

脈管侵襲の著明な症例

そ の 他：肛門括約筇機能低下例 poor risk 症例

表 3 低位前方切除術の非治曒症例

\begin{tabular}{|c|c|}
\hline 韭治疻切 除例 & $\begin{array}{r}5 \text { 例 } / 54 \text { 例 } \\
(9.39)\end{array}$ \\
\hline \multicolumn{2}{|l|}{ 非治瘜切除の理由 } \\
\hline 肝 転 移 & 2 例 \\
\hline $\mathrm{n}_{4}(+)>\mathrm{R}_{3}$ & 1 \\
\hline $\mathrm{n}_{4}(+)>\mathrm{R}_{2}$ & 1 \\
\hline 肺 転 移 & 1 \\
\hline ew $(+)$ & 1 \\
\hline
\end{tabular}

に久ける可能性があり，直腸切断術の施行が妥当と考え られているものである。

腫瘍の局所条件について検討すると，腫瘍が全周にお 上ぶ症例，最大径が $5 \mathrm{~cm}$ 以上に拉よぶ症例，非限局型 で浸潤の著明な症例などが挙げられているが，大きさの みでは必ずしも適忘の可否を決定する因子とはならず， プラス $\alpha$ の要素が加味されるものと考える. 非限局型腫 瘤の場合には癌の遺残の問題を考えると妥当なむのと考 える.

組織学的条件として，低分化癌，服管侵襲の著明な例 が挙げられ，その他の条件として肛門括約䇟機能が低下 している症例では，低前切後の排便機能は必ずしも良好 とはいえず，むしろ人工肛門の造設が日常生活面で良好 な場合もあり，患者の立場，社会生活などを含めた十分 な配慮が必要である。

\section{6. 低位前方切除と非治療切除}

表 3 は教室に㧍ける低前切施行症例のうち非治癒切除 症例を示したものである.すなわち低前切施行54例中， 非治㵂切除例は 5 例 $(9.3 \%)$ で, 非治瘉となった理由法 肝転移 2 例, 4 群リンパ節転移 1 例， 3 群リンパ節郭清 不十分 1 例，肺転移 1 例，ew（+）1 例となる.

表 4 は 116 施設のアンケート調查による非治瘉切除を 
表 4 低位前方切除之非治存切除

(アンケート調査)

\begin{tabular}{|c|c|}
\hline \multicolumn{2}{|l|}{ アンケート回答：116 施設 } \\
\hline 低位前方切除症例 & 3,725 例 \\
\hline 非治癒切除例 & 556 例 (14.9\%) \\
\hline \multicolumn{2}{|l|}{ 非治逾切除の理由 } \\
\hline & (96) \\
\hline 肝 転 移 & 34.0 \\
\hline $\mathrm{n}_{4}$ 転移， $\mathrm{R}<\mathrm{n}$ & 22.0 \\
\hline 腹膜播 種 & 17.9 \\
\hline 腹朌外転移 & 6.9 \\
\hline ew $(+)$ & 6.9 \\
\hline aw $(+)$ & 6.4 \\
\hline $\mathrm{Si}, \mathrm{Ai}(+)$ & 4.1 \\
\hline その他（重複癌, 高龄） & 1.8 \\
\hline
\end{tabular}

表 5 直腸癌に対する前方切除術後の 5 年生存率

（教 室 例）

\begin{tabular}{cl}
\hline 低位前方切除 & $63.2 \%(12 / 19$ 例 $)$ \\
〔3 年生存率 & $76.5 \%(26 / 34$ 例 $)]$ \\
高位前方切除 & $68.8 \%(11 / 16$ 例 $)$ \\
\hline
\end{tabular}

示したものである.すなわち低前切 3,725 例中，非治瘉 切除例は 556 例 $(14.9 \%$ )を占める. 556 例について非 治瘉切除となった理由をみると最も多いものが肝転移で $34 \%$ を占め, 以下， 4 群リンパ節転移, リンパ節郭清不 十分 $22 \%$, 腹膜播種 $17.9 \%$, 腹䐋外臓器転移 $6.9 \%$, ew (+) $6.9 \%$, aw (+) $6.4 \%$, si, ai (t) $4.1 \%$, その他 $1.8 \%$ と続くが, ew, aw (+) 症例がみられることは症 例の選択，手術手技の改善など考慮されるべきところで ある。

\section{7. 前方切除術後 5 年生存率}

表 5 は教室における 5 年生存率を示した.いまだ 5 年 経過症例が少ないが低位前方切除は63.2\%で，高位前方 切除の $68.8 \%$ と比較して大差は認めない，ちなみに低前 切の 3 年生存率汁 $76.5 \%$ である.

表6はアンケート結果であるが，各10例以上の報告施 設中，最も良好な成績は高位前方切除では $90 \%$ ，低位前 方切除では $82.4 \%$ であった. また54施設の報告の集計で は高位前方切除の 5 年生存は241例 $/ 398$ 例 $(60.6 \%)$ で あり，低位前方切除は82施設，673例/1080例（62.3\%） で，両者間には有意差を認めず，低前切は適応を十分考 慮することによって好成績が得られるものといえる。

\section{8. 低位前方切除と器械吻合}

教室では1979年 3 月以来，米国製 autosuture EEA を
表 6 アンケート調查加らた 前方切除術後 5 年生存率

(1974 1983)

\begin{aligned} & \hline 高位前方切除 $(54$ 施設 $) \\ & 60.6 \%(241$ 例 $/ 398$ 例 $) \\ &$ 低位前方切除 $(82$ 施設 $) \\ & 62.396(673$ 例 $/ 1080$ (例 $) \\ &$\hline\end{aligned}

表 7 吻合部の位置と释合不全

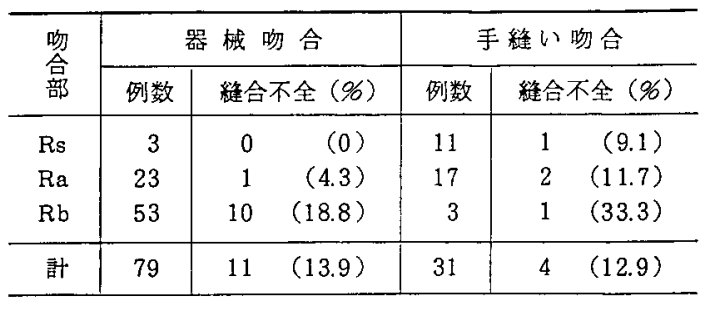

(1979.3～1983.11,柇暒医大 1 外)

採用し，1983年12月までに下部腸管手術79例に使用し; そのうち低位前方切除は42例，高位前方切除は22例であ る. 器械吻合には長所, 短所があるが，狭い手術野でも 均一な吻合が可能であり，低前切は理想的な適応のひと つといえる.しかしながら器械吻合にも縫合不全，術後 狭窄，出血などの合併症があるのは当然であり，教室例 について検討した.

表 7 は 4 年10ケ月に施行した器械吻合79例と手縫い吻 合31例の縫合不全の発生を示したものである. 器械吻合 の縫合不全発生率は $13.9 \%$ であり，手縫い吻合の $12.9 \%$ とほぼ同率であり，かつ，吻合部が低位であるほど高率 である.さらにその発生部位を検討すると後壁の leakage が 5 例, 側壁の leakage が 4 例, 前壁では 1 例で 視野が悪くなる後壁での発生が多かった．その原因とし ては腸管断端での purse string suture の不完全, 内刃 による腸壁の切離が不充分であったこと，吻合腸管径の 違い， 口側腸管の血行障害などが考えられた.

器械吻合といえども縫合不全は避けられないとの理由 で，EEA 採用初期には手縫いによる補强縫合を付加乙 たが，縫合不全は補強縫合の有無とは直接関係はみられ なかったことから最近は補強縫合を付加しないことを原 則としている.

一方, 術後の吻合部狭窄は表 8 亿示すように全周にわ たって補强綘合を加えた症例に発生しており，器械吻合 のみでは著明な狭窄は経験していない，また吻合後部出 血については 1 例も経験していない。

以上, 器械吻合に関する 2,3 の問題について教室例 
表 8 補強㹤合の付加亡昒合部狭窄

\begin{tabular}{|c|c|c|}
\hline & 例数 & 吻合部狭窄 \\
\hline 器械吻合十補強释合（全周） & 27 & 4 \\
\hline 器械劼合+補强艂合 (一部) & 4 & 0 \\
\hline 器械勄合のみ & 48 & 0 \\
\hline 尌 & 79 & 4 \\
\hline
\end{tabular}

(1979.3 1983.11, 札幌医大 1 外)

について述べたが，低位前方切除に際しては，器械のメ リットを十分発揮させるとともに，器械に頼りすぎた安 易な吻合操作は禁もつであることを常に念頭において対 処すべきで市る。

\section{9. 前方切除術後の各種機能障害}

近年, 㨁腸癌手術は增加の一途をたどっており，それ に伴なって術後機能障害に対する関心もたかまってい る. 直腸切断術後の各種機能障害についてはすでに数々 の報告，発表がなされてきたが，前方切除術といえど む，その例にもれず各種の機能障害を生ずる1-8).よっ て39回日本大腸肛門病学会の開催を機会にその寒状を把 握する目的で，各施設の協力をえ，アンケート調查を施 行した結果について, 教室例と併せて報告する.

\section{1）排便機能障害}

表 9 は教室例について検討したものである，術後経過 期間から 6 ケ月以内， 6 个月以上 1 年以内， 2 年以上の 3 群に分け，各群について残存直腸が $2 \mathrm{~cm}$ 以内, $2 \mathrm{~cm}$ 以上 $4 \mathrm{~cm}$ 以内, $4 \mathrm{~cm}$ 以上 $6 \mathrm{~cm}$ 以内に分訬て検討与る と, 少数例ではあるが，直腸が $4 \mathrm{~cm}$ 以上の症例で排便

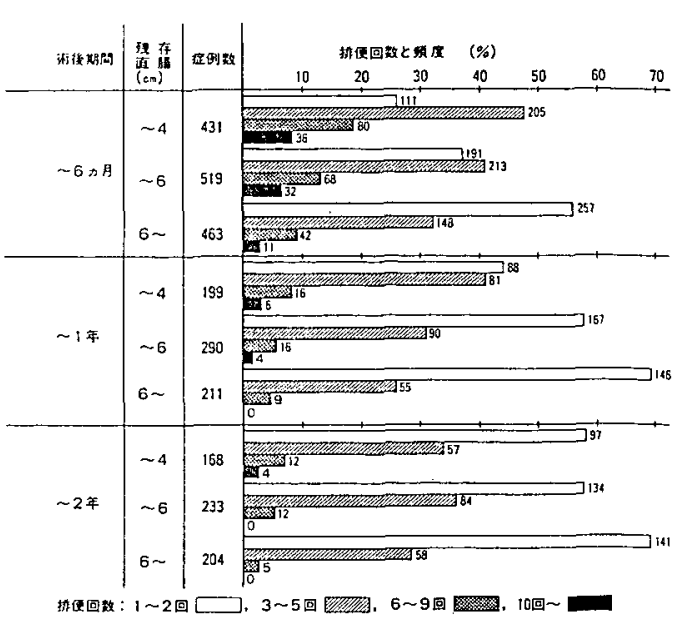

図 7 前方切除と排便障害（アンタート調查との1)

回数の減少がみられるのに対して， $2 \mathrm{~cm}$ 以内の症例で は 2 年以上を経過しても排便回数の隇少例は少なく, 便 とガスの識別不能例，便失禁例が多いことがわかる.

同様のことをナンケート調查の結果で検討すると図 7 に示すと打り，直腸が $4 \mathrm{~cm}$ 以内の症例は 2 年を経過し ても10回以上の排便回数を示寸症例が若干ではあるが認 められ，6〜9 回の症例も $4 \mathrm{~cm}$ 以上の症例にくらべて 多くなっているが，直腸が豎い症例ほど術前にちかく復 している.さらに表10のと括り便とガスの識別不能例， 便失禁例恃直腸が $4 \mathrm{~cm}$ 以内の症例で有意に多く，若干 例ではあるが， $6 \mathrm{~cm}$ 以上の症例にも認められることが ある点を念頭におくべきである.

2）排尿障害

表 9 前方切除術後の排便機能障害

（教 室 例）

\begin{tabular}{|c|c|c|c|c|c|c|c|c|c|c|}
\hline \multirow{2}{*}{\multicolumn{2}{|c|}{$\frac{\text { 術後 経 過 }}{\begin{array}{c}\text { 残存直 腸 } \\
(\mathrm{cm})\end{array}}$}} & \multicolumn{3}{|c|}{ 〜 6 力月 } & \multicolumn{3}{|c|}{ ～ 1 年 } & \multicolumn{3}{|c|}{2 年 } \\
\hline & & $\sim 2$ & $\sim 4$ & $\sim 6$ & $\sim 2$ & $\sim 4$ & $\sim 6$ & $\sim 2$ & $\sim 4$ & $\sim 6$ \\
\hline \multicolumn{2}{|c|}{ 症 例 数 } & \multicolumn{3}{|c|}{5} & 2 & 6 & & \multicolumn{3}{|c|}{21} \\
\hline 排 & $1 \sim 2$ & \multirow{3}{*}{\multicolumn{2}{|c|}{$\begin{array}{c}5 \\
(100.0)\end{array}$}} & & & $\begin{array}{c}1 \\
(16.7)\end{array}$ & & $\begin{array}{c}2 \\
(33.3)\end{array}$ & $\begin{array}{c}8 \\
(38.1)\end{array}$ & \\
\hline $\begin{array}{l}\text { 便 } \\
\text { 回 }\end{array}$ & $3 \sim 5$ & & & & $\begin{array}{c}1 \\
(50.0)\end{array}$ & $\begin{array}{c}4 \\
(66.6)\end{array}$ & & $\begin{array}{c}2 \\
(33.3)\end{array}$ & $\begin{array}{c}10 \\
(47.6)\end{array}$ & $\begin{array}{c}3 \\
(20.0)\end{array}$ \\
\hline 数 & $6 \sim 9$ & & & & $\begin{array}{c}1 \\
(50.0)\end{array}$ & $\begin{array}{c}1 \\
(16.7)\end{array}$ & & $\begin{array}{c}2 \\
(33.3)\end{array}$ & $\begin{array}{c}3 \\
(14.3)\end{array}$ & \\
\hline \multicolumn{2}{|c|}{$\begin{array}{l}\text { 便とガスの } \\
\text { 識別不能 }\end{array}$} & \multicolumn{3}{|c|}{$\begin{array}{c}2 \\
(40.0)\end{array}$} & $\begin{array}{c}1 \\
(50.0)\end{array}$ & $\begin{array}{c}2 \\
(33.3)\end{array}$ & & $\begin{array}{c}3 \\
(50.0)\end{array}$ & $\begin{array}{c}4 \\
(19.0)\end{array}$ & $\begin{array}{c}1 \\
(6.6)\end{array}$ \\
\hline & 失 禁 & & $\begin{array}{c}2 \\
(40.0\end{array}$ & & $\begin{array}{c}1 \\
(50.0)\end{array}$ & $\begin{array}{c}1 \\
(16.7)\end{array}$ & & $\begin{array}{c}3 \\
(50.0)\end{array}$ & $\begin{array}{c}4 \\
(19.0)\end{array}$ & \\
\hline
\end{tabular}


表 10 前方切除亡排便障害（アンケート調査その 2)

\begin{tabular}{c|ccc|ccc|ccc}
\hline 術後期間 & \multicolumn{3}{|c|}{$\sim 6$ 力月 } & \multicolumn{3}{|c|}{$\sim 1$ 年 } & \multicolumn{3}{c}{$\sim 2$ 年 } \\
\hline $\begin{array}{c}\text { 残存直 腸 } \\
(\mathrm{cm})\end{array}$ & $\sim 4$ & $\sim 6$ & $6 \sim$ & $\sim 4$ & $\sim 6$ & $6 \sim$ & $\sim 4$ & $\sim 6$ & $6 \sim$ \\
\hline 症 例 数 & 431 & 519 & 463 & 199 & 290 & 211 & 168 & 233 & 204 \\
\hline $\begin{array}{c}\text { 便之ガスの } \\
\text { 識 別不 能 }\end{array}$ & 43 & 19 & 10 & 9 & 7 & 2 & 4 & 5 & 3 \\
$(\%)$ & $(10.0)$ & $(3.7)$ & $(2.2)$ & $(4.5)$ & $(2.4)$ & $(0.9)$ & $(2.4)$ & $(2.1)$ & $(1.5)$ \\
\hline 便 失 禁 & 73 & 38 & 19 & 20 & 36 & 23 & 16 & 11 & 6 \\
$(\%)$ & $(16.9)$ & $(7.3)$ & $(4.1)$ & $(10.0)$ & $(12.4)$ & $(10.9)$ & $(9.5)$ & $(4.7)$ & $(2.9)$ \\
\hline
\end{tabular}

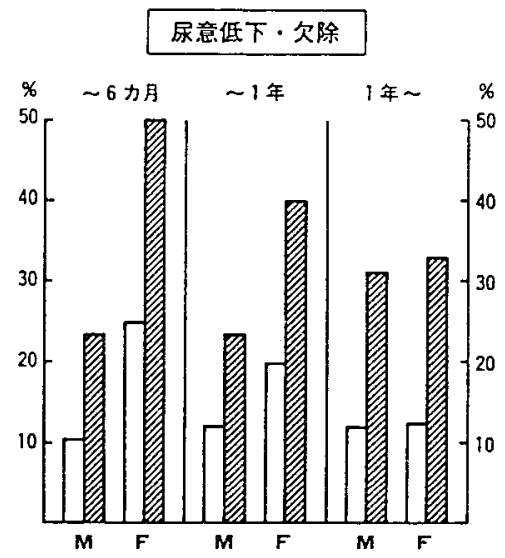

自力排尿不能

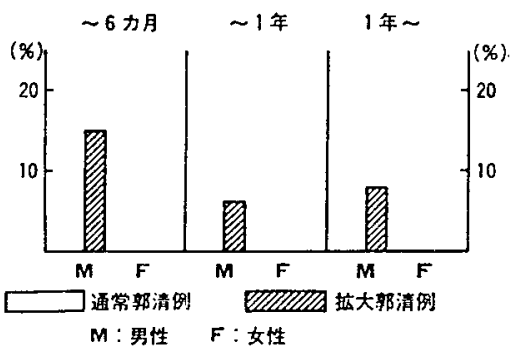

図 8 前方切除後の排尿障害 (その 1$)$

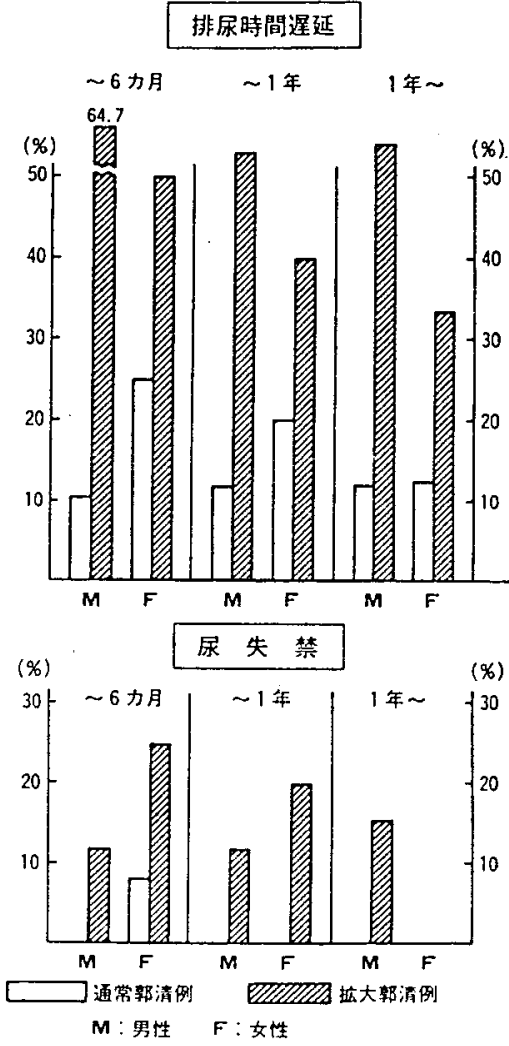

図 9 前方切除後の排尿障害 (その 2$)$
図 8 は教室例の排尿障害を示したが，低前切後に尿意 低下，欠除のある症例は意外に多く，男女間に多少の差 は認められるものの術後 1 年以上を経過しても改善のみ られない症例がみられ，とくに桩大郭清例で著明であ る.

自力排尿不能例は全て男性の拡大郭清例で認められる が，女性では回答が得られなかった。図 9 は排尿時閒の 遅延症例と尿失禁症例を示したが，男女ともに拉大郭清 例で高率に障害が認められ，男性の拡大郭清例では術後
1 年を経過してもなお，約半数例に排尿時間が遅延して いる. 尿失禁についても同样に拡大郭清例で認められ る.

つぎに同様のことをアンケート調查で検討した．図10 怯尿意就よ゙自力排尿についての集計結果で，ともに経 過年数とともに術前の状態に復していくが，拡大郭清施 行例では成績が恵寅く，とくに男性で目立っている.さら に排尿時間の延長，尿失禁なども図11に示すと抬り，い ずれも桩大郭清症例で目立っており，術後 2 年を経過し 


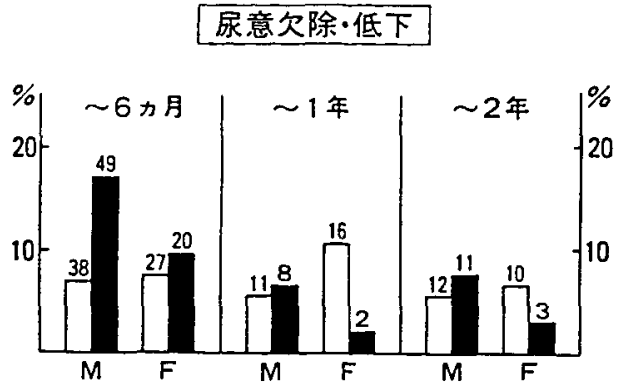

自力排尿不能

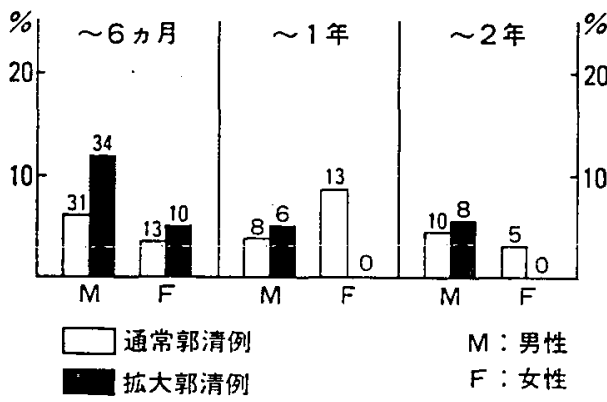

（数字は実数を示す）

図10 前方切除後の排尿障害(アンケート調查)

表 11 術後排尿障害に対する対策

(アンケート調查)

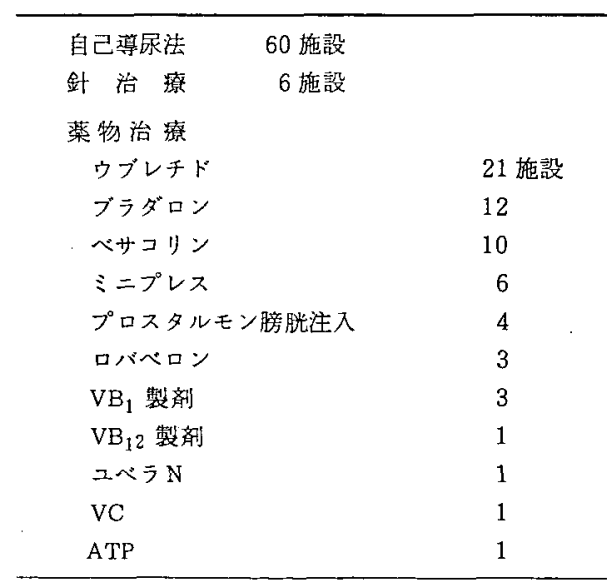

た時点でも排尿時間の遅れは $10 \sim 15 \%$ ，尿失禁は $5 \%$ 前 後に認められている．また通常郭清例といえどむ排尿障 害を伴なう症例があることを銘記しなければならない，

以上の排沓障害への効策としては，表11のものが施行 されており，最も普遍的なものは自己導尿法で 116 施設
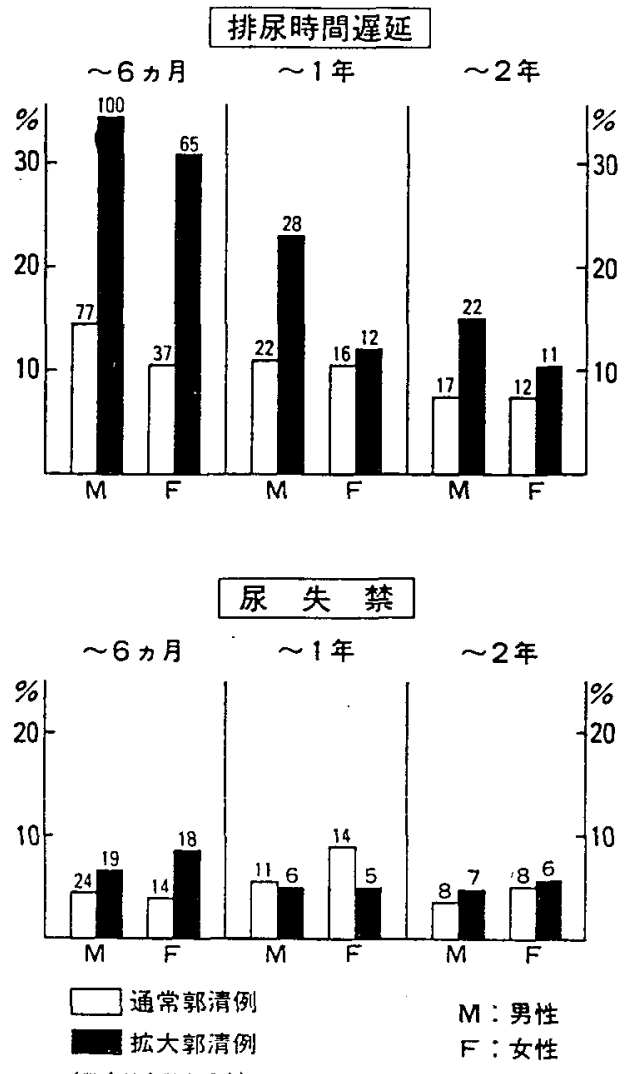

図11 前方切除後の捀尿障害 (アンケート調查)

中60施設から回答をえた。そのほかに針治療や，薬物療 法として各種の薬剤が用いられているが，その効果は不 明である。

3) 性機能障害

性機能障害もまた深刻な問題である. 表12は教室例に ついて検討したものであるが，男性では射精障害，勃起 障害ともに通常郭清群の $55 \%$ に，拉大郭清群では $90 \%$ 前 後に認められ，女性では $60 \%$ 前後がオルガスムの低下を 訴えている.

つぎに22施設からのアンケート結果の集計でも，表13 のと抢り报大郭清のいかんを問わず高率で性機能障害が 認められ，とくに勃起障害より射精障害が高率となって いる.

以上の各種機能障害については患者の訴えをまつのみ ではなく，医師側からの積極的なアプローチによって明 らかになる症例が多く，とくに男性の性機能に関して は，人知れず樑刻に悩んでいる患者の多いことを，われ われは常に銘記すべきである.よって一方では根治性を 損わず，また一方では機能障害のより少ない神経温存手 術など機能保全手術に対する一層の研究努力が要求され 
表 12 前方切除術と性機能障害

（教 室 例）

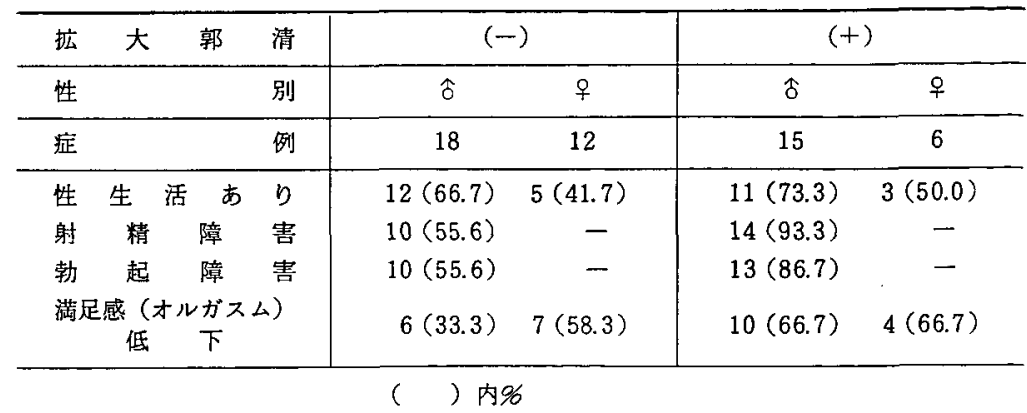

表 13 前方切除後の性機能障害

(アンケート集計：22 施設）

\begin{tabular}{|c|c|c|c|c|c|c|c|}
\hline 拡 & 大 & 郭 & 清 & \multicolumn{2}{|c|}{$(-)$} & \multicolumn{2}{|c|}{$(+)$} \\
\hline 性 & & & 別 & $\hat{0}$ & 우 & $\hat{\sigma}$ & 우 \\
\hline 症 & & & 例 & 207 & 63 & 126 & 34 \\
\hline 性 & 生 & あ & $\eta$ & $100(48.3)$ & $31(49.2)$ & $52(41.3)$ & $17(50.0)$ \\
\hline 射 & 精 & 障 & 害 & $150(72.5)$ & - & $110(87.3)$ & - \\
\hline 勃 & 起 & 障 & 害 & $106(51.2)$ & - & $89(70.6)$ & - \\
\hline & 感（ & $\begin{array}{c}\text { レガス } \\
\text { 下 }\end{array}$ & & $37(17.9)$ & $14(22.2)$ & $22(17.5)$ & $16(47.1)$ \\
\hline
\end{tabular}

(1984.9)

るところである。

\section{むすび}

直腸滰に対する各術式のうち，比較的機能障害が少な く，近年，数多く施行されるようになった低位前方切除
術の適応とその予後，とくに各種機能障害の面から，教 室例と併せて全国集計の結果について述べた.

終りに今回のアンケート調査にご協力いただいた施設 の各位に深甚なる謝意を表するものである.

\section{アンケートに協力いいだいた施設}

\section{北海道地区}

北海道大学第 1 外科

市立札幌病院外科

坦川医科大学第 2 外科

市立䞟川病院外科

\section{東北地区}

弘前大学第 1 外科

弘前大学第 2 外科

国立弘前病院外科

八户市民病院外科

盛岡赤十字病院外科

東北大学第 1 外科

宮城罟立成人病センター外科

福島学災病院外科

\section{関東地区}

新潟大学第 1 外科

新潟県立がえセンター外科

独協医科大学第 1 外科

群馬大学第 1 外科

埼玉県立がんセンター外科

埼玉医科大学第 1 外科

千葉大学第 1 外科

千葉大学第 2 外科

武藏野赤十字病院外科

国立がんセンター外科

国立病院医療センター外科

国立大蔵病院外科

都立荏原病院外科
都立大久保病院外科

都立駒込病院外科

都立広尾病院外科

虎の門病院外科 .

東京医科画科大学第 1 外科

東京医科齿科大学第 2 外科

東京厚生年金病院外科

癌研究会附属病院外科

杏林大学第 2 外科

慶応義塾大学外科

順天堂大学第 1 外科

帝京大学第 1 外科

帝京大学第 2 外科

帝京大学溝口病院外科 
東京医科大学外科

日本大学第 3 外科

日本医科大学第 2 病院外科

昭和大学豊州病院外科

慈患会医科大学第 2 外科

慈恵会医科大学第 3 病院外科

慈患会医科大学青戸分院外科

東邦大学第 1 外科

東邦大学第 2 外科

東京女子医科大学消化器病センタ

社会保険中央綾合病院外科

東京大学第 1 外利

横浜市立大学第 2 外科

東京警察病院外科

関束労災病院外科

川崎市立井田病院外科

\section{中部地区}

信州大学第 1 外科

金沢大学第 2 外科

富山医科蒋科大学第 2 外科

金沢医科大学一般消化器外科

福井医科大学籘 1 外科

岐帛大学第 1 外科

岐皋市民病院外科

県立㖅㚖病院外科

大垣市民病院外科

要知医科大学第 1 外科
名古屋大学第 1 外科

名古屋大学第 2 外科

名古屋市立大学第 1 外科

名古屋保健衛生大学消化器外科

中部労災病院外科

三重大学第 1 外科

三重大学第 2 外科

市立四日市病院外科

静岡県立総合病院外科

県西部浜松医療センター外科

浜松医科大学第 2 外科

\section{近畿地区}

大阪医科大学一般消化器外科

大阪厚生年金病院外科

大阪学災病院外科

関西医科大学外科

大阪市立大学第 1 外科

大阪府立成人病センター外科

近畿大学第 1 外科

大阪赤十字病院外科

国立大阪病院外科

和歌山医科大学消化器外科

兵庫医科大学第 1 外科

兵庫医科大学第 2 外科

神戸大学第 1 外科

神戸労災病院外科

神戸中央市民病院外科

京都大学第 1 外科
京都隹立医科大学第 2 外科

国立京都病院外科

\section{中国地区}

鳥取大学第 1 外科

島根医科大学第 2 外科

岡山济生会病院外科

川崎医科大学消化器外科

広島大学第 2 外科

広岛大学原医研外科

\section{四国地区}

香川医科大学第 1 外科

徳島大学第 1 外科

徳島大学第 2 外科

松山赫十字病院外科

愛媛大学第 2 外科

高知県立中央病院外科

\section{九 州地区}

九州大学第 2 外科

国立九州がんセンター外科

久留米大学第 1 外和

佳賀医科大学外科。

国立熊本病院外科

鹿㫛島大学第 1 外科

大分缚立病院外科

九大生体防禦医研外科

宮崎医科大学第 2 外科

琉球大学第 2 外科

以上 116 施設

\section{文献}

1）柳田謶蔵，五户達雄，吉雄敏文ほか：術後機能り ハビリテーションを中心とした直腸癌の治療. 手 術 $29: 831-841 ， 1975$

2）岀富正幸，多开正大，吉川守：直腸澏におけ方 括約筋保存手術. 外科治療 $36: 58-68,1977$

3）粕川剛義：值腸癌における括約筋保存手術こその 成績について。外科治療 $36: 69-84,1977$

4) 加藤王千, 加藤知行, 中里博昭ほ加: 直腸切断術 後の排便，排尿扝よび性機能障害とその対筑，手 術 $34: 1489-1495,1980$

5）土屋周二，江口英越，中村 清ほ加：直腸癌括約 笳温存手術後の排便機能. 外科診療 22 : 16451651,1980

6) 安富正幸, 福原 效：括約筋温存術式の再检討： 直腸癌江対する括約筋保存手術の適応と選抧. 臨 床外科 35:991-997，1980

7）江口英雄, 大木繁男, 大見良裕ほか：直腸癌に㧍 ける拡大郭清の意義一拡大郭清と機能障害--. 臨 床外科 $35:$ 1014-1019，1980

8）寺本 滋, 小松原正吉: 大腸㶅術後機能障害と合 併症。 日本臨床 $39: 2174-2179,1981$

\section{シンポジゥムI：病期別にみた進行大腸癌の 治療と予後}

S I -1 教室における大腸癌の外科治療とその成績 一七くに予後を左右する因子についてー

東京大学第 1 外科 沢田 俊夫ほか

S I -2 病期別にみた進行大腸癌の治療と予後 一中期癌と晚期癌について一

鹿児島大学第 1 外科石沢隆ほか

S I -3 病期別にみた進行直腸癌の治療と予後

久留大学第 1 外科 林田 哲介ほか

S I -4 大腸癌非治瘉症例に招ける姑息的切除術と非切 除術の予後

京都大学第 1 外科 前谷 俊三ほか

S I -5 進行大腸癌の治療と子後

愛知罚がんセンター外科第 3 部 加藤 知行ほか

S I -6 大腸癌肝転移に対する治療

東京医科歯科大学第 2 外科 八重樫寛治ほか 